\title{
Cost efficiency and financial situation of local governments in the Canary Isles during the recession
}

\section{Diego Prior ${ }^{\mathrm{a}}$, Ignacio Martín-Pinillos-Castellanos ${ }^{\mathrm{b}}$, Gemma Pérez-López ${ }^{\mathrm{c}}$, José L. Zafra- Gómez $^{d}$}

a) Universitat Autònoma de Barcelona, Spain

b) Universidad de la Laguna, Spain

c) Facultad de Ciencias Económicas y Empresariales, University of Granada, Spain

d) Universidad de Granada, Spain

\author{
${ }^{d}$ Corresponding author. \\ E-mail address: jlzafra@ugr.es
}

\section{A R T I C L E I N F O}

\section{Article history:}

Received 21 March 2018

Accepted 4 December 2018

Available online 1 July 2019

JEL classification:

Keywords:
Efficiency
Financial condition
Borrowing
Local public sector
Order-m

Order-m

Códigos JEL:

Palabras clave:

Eficiencia

Condición financiera

Endeudamiento

Sector público local

M-Order

\section{A B S T R A C T}

This paper examines cost efficiency in the Spanish municipal public sector, in a specific geographic area (the Canary Isles, Spain), with respect to financial condition and different types of municipal debt. The study focuses on municipalities dependent on tourism and on the consequences to them of the Great Recession, doing so via a two-stage analysis. In the first, the order-m method is used to evaluate the cost efficiency of 77 Canary Isles municipalities, for the period 2008-12. In the second stage, we examine the effect produced on cost efficiency by different types of borrowing (long term, short term, financial and commercial) together with other financial, economic, political and quality variables, using the model developed by Simar and Wilson (2007), based on a truncated bootstrap regression with panel data. Empirical analysis shows that in times of crisis there is a significant relationship between the components of financial condition and cost efficiency. Inconclusion, municipal cost efficiency increases with commercial debt, but decreases with financial debt. Furthermore, certain socioeconomic variables affect the levels of cost efficiency.

C2019 ASEPUC. Published by EDITUM - Universidad de Murcia. This is an open access article under the CC BY-NC-ND license (http://creativecommons.org/licenses/by-nc-nd/4.0/).

Condición financiera y eficiencia en los gobiernos locales de las Islas Canarias en tiempos de crisis financiera.

R E S U M E N

Este trabajo examina la eficiencia de costes para el caso particular del sector público municipal español, concretamente, para el caso de los municipios canarios, poniendo especial énfasis en áreas relacionadas con la condición financiera y diferentes tipologías de deuda, teniendo en cuenta las características propias que estos municipios poseen, como un índice turístico elevado. En primer lugar, se utiliza el método de orden m para evaluar la eficiencia de costes de 77 municipios de las Islas Canarias, para el período 2008-12. En la segunda etapa, examinamos el efecto producido en la eficiencia de costes por diferentes tipologías de endeudamiento (largo plazo, corto plazo, financiero y comercial) junto con otras variables financieras, económicas, políticas y de calidad, utilizando el modelo desarrollado por Simar y Wilson (2007), basado en una regresión truncada con datos de panel. Nuestro análisis empírico muestra que en tiempos de crisis existe una relación significativa entre los componentes de la condición financiera y la eficiencia de costes. En particular, concluye que mientras la eficiencia de los costes municipales aumenta con la deuda comercial, disminuye con la deuda financiera. Además, mostramos que ciertas variables socioeconómicas afectan los niveles de eficiencia de costes.

C2019 ASEPUC. Publicado por EDITUM - Universidad de Murcia. Este es un artículo Open Access bajo la licencia CC BY-NC-ND (http://creativecommons.org/licenses/by-nc-nd/4.0/). 


\section{Introduction}

The recent economic and financial crisis forced local governments to seek a more efficient allocation of their resources, due to the need to provide the same level of services with increasingly limited means (López-Hernández et al., 2012). Among other causes, this situation of scarce resources has arisen from falling public administration revenues, the increased competences acquired in recent years (Balaguer-Coll, 2004), greater demand for public services and the enactment of legislation ${ }^{1}$ strengthening economicfinancial control over local entities (as indicated in the preamble to Act 27/2013, of 27 December, on the Rationalisation and Sustainability of Local Administration). This background, and the fact that municipal government is the level of public administration that is closest to the citizen, underlies academic interest in analysing municipal management performance (Zafra-Gómez \& Muñiz, 2010) and thus in evaluating the factors that determine efficiency (Bosch et al., 2012), especially those related to sources of funding.

In this context, it is especially important to analyse public sector borrowing, as local managers might raise levels of public debt in order to compensate for lags and gaps between municipal income flows and costs. Studies of efficiency and borrowing have hypothesised that there may be an inverse relation between these two elements due to the substitution effect of borrowing for own resources, in what has been termed a fiscal illusion (Cabasés et al., 2007; Pérez-López et al., 2014), and to the impossibility of reducing public spending (Worthington, 2000; Geys, 2006; Da Cruz \& Marquez, 2014).

In view of these considerations, one of the main objectives of our paper is to analyse the different characteristics of borrowing and their relationship with cost efficiency, an area that we believe has been insufficiently addressed in previous research, with special emphasis on the detailed analysis of different types of borrowing, distinguishing between short and long-term borrowing, and commercial and non-commercial borrowing, seeking to determine whether their particular characteristics influence municipal cost efficiency, especially in municipalities dependent on tourism and taking into account the impact of the Great Recession (the most recent transboundary crisis) on levels of municipal efficiency and financial condition (Ansell et al., 2010; López-Hernández et al., 2017; Plata-Diaz et al., 2017). In relation to this study goal, we propose a series of hypotheses on which to base our analysis of the impact made by certain economic, financial and political factors on cost efficiency.

A twofold approach is taken to achieve these goals: first, order-m frontiers are used to calculate cost efficiency. This concept was introduced by Cazals et al. (2002) and later used by Simar (2003), who used a non-parametric model to address the main problems encountered in data envelopment analysis (DEA), a method that has been widely used in recent years, although rarely for the purpose of evaluating municipal efficiency (Balaguer-Coll et al., 2007; PérezLópez et al., 2015; Narbón-Perpignan \& De Witte, 2018a). In the second phase of this study, the determinants of cost efficiency are analysed in accordance with the method proposed

\footnotetext{
${ }^{1}$ The general legislation on Spanish local government, particularly Local Government Act 7/1985 of 2 April (LRBRL); the local government financial regulations in Spain, in particular the Local Government Finance Act, approved by Royal Legislative Decree 2/2004, of 5 March 5 (TRLRHL); and the regulations on budgetary stability applicable to local government, which includes, in general, Organic Act 2/2012, of 27 April, on Budgetary Stability and Financial Sustainability, and its subsequent amendment Organic Act 4/2012, of 28 September (LEPSF).
}

by Simar and Wilson (2007), which offers more robust results than other models such as ordinary least squares (OLS) or Tobit (Da Cruz \& Marques, 2014), applying a truncated bootstrap regression with panel data and fixed effects. Many previous studies of the influence of certain factors on cost efficiency have used Tobit models or bootstrap truncated regression with cross section data. In our opinion, the approach adopted in the present study provides greater robustness to the analysis of the relationships considered. In this empirical study, the sample population consists of 77 municipalities in the Canary Isles, Spain (accounting for $83.5 \%$ of the total municipalities in the archipelago), all of which have fewer than 50,000 inhabitants.

The results obtained show that short-term borrowing, compliance with credit limits, the index of budget sustainability and fiscal pressure per capita all present a significant inverse relationship with cost efficiency. On the other hand, commercial borrowing and the index of public service quality are positively related to cost efficiency. We also obtained evidence regarding the cost efficiency of other factors such as the exercise of municipal government by a progressive political party, of higher levels of population density and the significant presence of a population aged over 65 years. All these circumstances were associated with higher levels of cost efficiency.

This paper is structured as follows. After this introduction, Section 2 describes the theoretical framework employed, regarding cost efficiency, financial condition and municipal borrowing, and sets out the hypotheses to be tested. Section 3 provides a detailed description of the research method, the study sample and the input and output variables used to calculate cost efficiency, together with the variables used to analyse the financial-condition cost-efficiency relationship. Section 4 presents the results obtained, which are then discussed in Section 5 , followed by a summary of the main conclusions drawn.

\section{Theoretical framework for local government efficiency}

\section{Cost efficiency and financial condition in municipal govern- ment}

Cost efficiency and the factors that affect it have been widely considered in previous research (De Borger \& Kerstens, 1996a, 1996b; Prieto \& Zofio, 2001; Balaguer-Coll, 2004; Balaguer-Coll et al., 2007; Balaguer-Coll \& Prior, 2009; Benito et al., 2010; Bisogno \& Cuadrado-Ballesteros, 2018; Cuadrado-Ballesteros \& Bisogno, 2018; Narbón-Perpiñá \& De Witte, 2018a;2018b) ), seeking to identify inefficient activities and to establish models based on local authorities found to be relatively efficient. However, a more detailed understanding is needed of the relationship between cost efficiency and relevant financial factors, measured according to the concept of financial condition (Zafra-Gómez \& Muñiz, 2010). Accordingly, the first step is to consider which concepts of efficiency and financial conditionshould be used.

Public administrators must decide which services should be provided to citizens, and the quantity and quality of these services. To enable them do so, the preferences of society must be determined, by reference to the elements characterising the demand for municipal services (Balaguer-Coll et al., 2007; Zafra-Gómez \& Muñiz, 2010, Pérez-López et al., 2015).

Various theoretical approaches have been developed to consider the most appropriate response to citizens' needs regarding the quantity and quality of goods and services 
provided. In particular, within the framework of the Theory of Local Public Expenditures (Tiebout, 1956), it has been argued that if there were more competition between local jurisdictions, municipal services would be more efficient, i.e. governments would use their resources in a way that minimised the cost of providing local public services. On the other hand, according to the Median Voter theory, citizens decide the level of expenditure they require by voting accordingly, opting for the candidate offering the greatest service efficiency (i.e. services provided with respect to taxes paid) (Congleton, 2002). As difficulties can arise in identifying citizens' preferences, the theoretical approach of structuralism advocates measuring them through proxy variables such as the demographic, socioeconomic and fiscal factors within a community that affect the provision of public services (Hammer \& Green, 1996).

Of the different types of efficiency - technical or productive efficiency, allocative or cost efficiency, distributive efficiency and dynamic efficiency (Andrews \& Entwistle, 2013) - in studies of local government, that of allocative or cost efficiency is commonly used (Vanden Eeckaut et al., 1993; De Borger \& Kerstens, 1996; Zafra-Gómez \& Muñiz, 2010), due to the complexity of measuring economic efficiency, among other reasons because production prices are often not available and because outputs are (totally or partially) determined externally (Balaguer-Coll \& Prior, 2009; Pérez-López et al., 2015).

There are various reasons for wishing to determine overall efficiency rather than that of specific public services (Borge et al., 2008; Bosch, 2012; Pérez-López et al., 2015). On the one hand, as observed by Giménez and Prior (2007), municipalities provide multiple and varied public services, with the common objective of satisfying the needs of local citizens, and therefore it is appropriate to consider the efficiency of these public services as a whole. Furthermore, major difficulties may arise in selecting and quantifying for analysis the products and services offered by each municipality and in obtaining information on each of the services they provide independently (De Borger \& Kerstens, 1996). Finally, the availability of other types of information may make it more advisable to analyse overall efficiency, since it makes no sense to assess the efficiency of services independently when the variables that will be used to analyse the factors refer to the municipality at the overall level (Borge et al., 2008).

In performing this analysis, it is necessary to be aware of the characteristics of local government financing, and its relation to efficiency, a question that has been addressed in various studies. Thus, Dijkgraaf et al. (2003) studied the relationship between efficiency and financial situation, and concluded that when the latter is difficult this forces municipal managers to improve service efficiency as a means of obtaining cost savings. Similarly, Zafra-Gómez and Muñiz (2010) analysed the relationship between efficiency and financial structure, observing that the most efficient municipalities are not those which have the best financial structure, but are characterised as presenting a degree of relaxation in the search for better financial margins, precisely because they are more cost efficient. Benito et al. (2010) studied the relationship between efficiency and the economic level of local government, and reached the conclusion that there is no significant relationship between the two. However, most of the correlations found were positive, which suggests there is some type of relationship between economic level and efficiency.

To properly address the relationship between efficiency and financial situation, we must define what is meant by the latter. In this respect, the literature refers to several concepts, often interchangeable, such as financial position or condition and fiscal stress, crisis or disaster. Among these terms, the broadest and most appropriate concept for evaluating the financial health of local government is that of financial condition (Zafra-Gómez \& López-Hernández, 2006; Zafra-Gómez et al., 2009a; Hendrick, 2011). Diverse theoretical frameworks have been proposed for defining financial performance (Hendrick, 2011; Turley et al., 2015). These are characterised by combinations of elements that may differ in their denominations, but, in general, use common indicators of liquidity, debt and budget surplus/deficit, among other parameters (Zafra-Gómez et al., 2009; Hendrick, 2011). Reviews of the literature in this field show that the concept of financial condition includes a greater variety of such elements with which to analyse the financial health of local administrations (Zafra-Gómez et al., 2009a; Zafra-Gómez et al., 2009b; Hendrick, 2011; Cabaleiro et al., 2013).

According to the Governmental Accounting Standards Board $^{2}$ (1987), financial condition can be defined as the ability to provide services whilst complying with present and future obligations. For Balaguer-Coll (2002, p.31), financial condition is the entity's capacity to meet its financial obligations, including the payment of interest and the repayment of debt, and its capacity to provide the level and quality of the services required for the welfare of its citizens, at an acceptable level of taxes. Hendrick (2011) defined financial condition as the state of equilibrium that exists between the different dimensions or components of the government's financial sphere in relation to its spending, obligations, fiscal resources, income and internal resources. Other authors, such as Greenberg and Hiller (1995), CICA (1997), ZafraGómez et al. (2006, 2009a), Groves et al. (2003) and Wang et al. (2007), have all developed particular views of this concept. In line with previous approaches in this field (ZafraGómez et al., 2006, 2009a; Cabaleiro et al., 2013) our study sample was composed following the approach recommended by CICA $(1997,2009)$, according to which proper measurement of financial condition should include a consideration of sustainability, flexibility and vulnerability.

For this purpose, sustainability is defined as the organisation's capacity to maintain, promote and preserve the social welfare of its citizens through the use of the resources at its disposition (Carmeli, 2002; PriceWaterhouseCoopers, 2006; Zafra-Gómez et al., 2009; Atan et al., 2010; Cabaleiro et al. 2013; Government of Western Australia: Department of Local Government, 2013). Flexibility is taken to be the organisation's ability to respond to changing economic and financial circumstances, within the limits of its fiscal capacity; this ability will be reflected in its reactions to such changes via increases in taxation levels, in public debt or in transfers received (Zafra-Gómez et al., 2009a, 2009b; Hendrick, 2011; Cabaleiro et al., 2013). Vulnerability is understood as the organisation's level of dependence on external funding in order to maintain public spending levels, via transfers, subsidies and grants (Carmeli, 2002; Atan et al., 2010; Cabaleiro et al., 2013; Government of Western Australia: Department of Local Government, 2013); Zafra-Gómez et al., 2009a, 2009b; Plata-Díaz et al., 2017).

\footnotetext{
${ }^{2}$ Established in 1984, the Governmental Accounting Standards Board (GASB) is the independent, private-sector organization based in Norwalk, Connecticut, that establishes accounting and financial reporting standards for U.S. state and local governments that follow Generally Accepted Accounting Principles (GAAP) (https://gasb.org. Accessed: 3 July 2018).
} 
Previous empirical evidence and its relation to the theoretical framework

Previous researchers in this field have placed special emphasis on the analysis of efficiency in local administrations, mainly through the use of non-parametric techniques by which inputs and outputs are determined. A unit of efficiency measurement is then configured, either using direct indicators or proxies (De Borger et al., 1994; De Sousa \& Stosic, 2005; Balaguer-Coll, 2004; Balaguer-Coll \& Prior., 2009; Borge et al., 2008; Balaguer-Coll et al., 2007); ZafraGómez \& Muñiz, 2010).

In analysing financial and fiscal factors, some authors have studied the relationships between cost efficiency and variables that represent indicators of the three aspects that define financial condition. Thus, Balaguer-Coll et al. (2007) reported an inverse relationship between cost efficiency and the index of budget sustainability. Vulnerability has been analysed by studying the level of transfers, and in this respect Geys (2006) reported that higher transfers were related to higher rates of efficiency. However, other authors have concluded that an increase in resources that are not obtained directly from citizens can provoke a 'fiscal illusion' effect, making municipal managers feel less pressured to achieve efficiency in the delivery of public services (Giménez \& Prior, 2007; Bosch et al., 2012). Flexibility can be analysed in terms of many variables, including debt, fiscal pressure and fiscal surplus (Zafra-Gómez et al., 2009a, 2009b; Hendrick, 2011; Cabaleiro et al., 2013).

Many studies have reported finding a negative relationship between debt and cost efficiency, explained by the presence of financial costs that increase public sector spending, thus reducing cost efficiency (Worthington, 2000; Geys, 2006; Benito et al., 2010; Da Cruz and Marques, 2014; Cordero et al., 2017). According to the literature on short-term borrowing (Worthington, 2000; Geys, 2006), this is an explanatory variable of cost efficiency, with which it is inversely related, due to the increased borrowing incurred when financial costs rise. However, an increase in long-term debt is associated with greater cost efficiency (Benito et al., 2010). Other variables, too, have been considered in this context. Thus, Geys (2006) and Pérez-López et al. (2014) reported finding a direct relationship between net savings and cost efficiency. Other studies have analysed the influence of fiscal pressure in this respect, producing conflicting results. Some papers have concluded that greater fiscal pressure may reduce cost efficiency, arguing that when local governments lose the power to generate current revenues, they become less motivated to manage their resources efficiently (De Borger et al., 1994; Balaguer-Coll, 2002; Giménez \& Prior, 2007; Balaguer-Coll et al., 2007; Balaguer-Coll \& Prior, 2009; Bosch et al., 2012; Cuadrado-Ballesteros et al., 2013). Others, however, affirm that high taxes can lead voters to require more control of public spending, and to urge public managers to improve cost efficiency (De Borger \& Kerstens, 1996; Balaguer-Coll et al., 2007; Benito et al., 2010).

\section{Research hypotheses}

According to the above considerations, the research hypotheses should contain the three elements proposed for measuring financial condition - sustainability, flexibility and vulnerability. The first of these is considered via the budget sustainability index, which reflects the relationship between the volume of local government spending and that of budget revenues. The higher the value of this indicator, the greater the budget deficit. Following Balaguer-Coll et al. (2007; p. 437), sustainability is expected to be inversely associated with efficiency, because a situation of deficit may be considered to represent a mismanagement of public resources and, therefore, reduced cost efficiency. Accordingly, the first research hypothesis is posed as follows:

Hypothesis 1: An increase in the budget deficit (sustainability) will reduce cost efficiency.

The second element used in this study to measure financial condition is that of vulnerability, i.e. the ratio of transfers received to total income. A high value for this indicator means that a large proportion of local government revenue is not obtained directly from the municipal population. This situation can give rise to the fiscal illusion that any expense can be met because there is sufficient income, and so municipal managers could perceive less pressure to operate more efficiently (Giménez \& Prior, 2007; Bosch et al., 2012). Other authors have associated the effect of fiscal illusion with lower levels of public interest in supervising the policies adopted by local government, an indifference that ultimately results in decreased cost efficiency (De Borger \& Kerstens, 1996; Balaguer-Coll, 2002; Balaguer-Coll et al., 2007; Borge et al., 2008; Balaguer-Coll \& Prior, 2009).

On the other hand, Geys (2006) reported that the larger the volume of government transfers received, the higher the index of cost efficiency, arguing that subsidies are subject to greater supervision and control, which limits the wasteful application of these resources. As there is no specific empirical evidence of the impact of this variable on cost efficiency, the second hypothesis merely suggests that an increase in the value of transfers will affect cost efficiency, without specifying its sign.

Hypothesis 2: An increase in the level of transfers (vulnerability) will affect cost efficiency.

The third element defining financial condition is flexibility, which is analysed by disaggregating the concept into three aspects: borrowing, the index of compliance with credit limits and fiscal pressure. Moreover, it is necessary to distinguish between short and long-term borrowing, commercial borrowing and financial borrowing. The variable 'net savings' is defined as the resources generated with the current budget that are really available to finance capital expenses, once the annual amortisation of the debt has been financed. A greater net saving must result either from increased income or from decreased spending (Pérez-López et al., 2014), and the lower the spending, the higher the cost efficiency. In other words, an increase in net savings will result in decreased spending and, hence, greater cost efficiency. Note that in Spain a prerequisite for requesting long-term funding, according to local government regulations ${ }^{3}$, is that the net savings balance for the previous year must have been positive.

Hypothesis 3a: An increase in positive net savings will increase cost efficiency.

An increase in the second of these variables, fiscal pressure per capita, defined as the ratio of municipal tax revenue to the number of inhabitants in the municipality, can harm cost efficiency because the local government could become less competent to generate current income, as a result of

\footnotetext{
${ }^{3}$ Article 53 of Legislative Decree 2/2004, of 5 March, approving the Consolidated Text of the Local Government Finance Act.
} 
being less motivated to manage its resources efficiently (De Borger et al., 1994; Balaguer-Coll, 2002; Giménez \& Prior, 2007; Balaguer-Coll et al., 2007; Balaguer-Coll \& Prior, 2009; Bosch et al., 2012; Cuadrado-Ballesteros et al., 2013). On the other hand, high local taxes might increase voters' demands for stricter control of public spending and thus spur public managers to greater cost efficiency (De Borger \& Kerstens, 1996; Balaguer-Coll et al., 2007; Benito et al., 2010).

Although there is no unanimity on this question in the literature, the following hypothesis proposes that an increase in taxes in relation to the number of local inhabitants will have a negative impact on cost efficiency. Thus:

Hypothesis $3 b$ : An increase in taxes per capita will reduce cost efficiency.

As previously explained, in this paper the question of flexibility receives special consideration, and is examined in terms of different indicators and types of borrowing. The literature is not unanimous on the influence of borrowing on cost efficiency (Balaguer-Coll et al., 2007; Benito et al., 2010). The theoretical argument most frequently used is to assume an inverse relationship between borrowing and efficiency, due to the presence of financial costs that raise the level of public spending and thus reduce cost efficiency (Worthington, 2000; Geys, 2006; Benito et al., 2010; Da Cruz \& Marques, 2014; Cordero et al., 2017). However, this conclusion might be distorted by the different types of government borrowing available, which could plausibly affect the above relationship. Therefore, one of the aims of this study is to disaggregate the borrowing variable according to the term of the debt and the nature of the financing entity.

Many previous studies have examined the relationship between cost efficiency and financial debt, but in this respect we should distinguish between long and short-term financial borrowing, as each type has its own characteristics that can influence levels of government cost efficiency in different ways. We adopt the initial premise that long-term financing can only be used for long-term investments and, in turn, short-term financing can only be used to cover cash shortfalls related to short-term debts. Indeed, these characteristics are typical of local government funding (Pérez-López et al., 2013, 2014). The view that short-term borrowing is an explanatory variable of cost efficiency and has an inverse relationship with this parameter may be justified by observing that increased borrowing takes place in response to rising financial expenses, as observed by Worthington (2000) and Geys (2006), and in consequence, cost efficiency deteriorates.

In consequence, the following hypothesis is divided into two elements: the first, on the relationship between cost efficiency and short-term borrowing, and the second, on its relationship with long-term borrowing.

Hypothesis 4a: Increased short-term financial debt is associated with reduced municipal cost efficiency.

An increase in borrowing that is used to finance investments in public facilities, in other words, long-term debt, can raise cost efficiency (Benito et al., 2010). In this case, the improvement in cost efficiency would be directly related to the volume of municipal investment, and so the following hypothesis is proposed.

Hypothesis 4b: There is a positive relationship between cost efficiency and long-term financial debt.
However, we must differentiate between these forms of borrowing and commercial debt, which may be related with cost efficiency in a different way. This contrast would arise from the fact that commercial borrowing does not usually incur financial costs, and so more income would be available for application to municipal services. As costs would not thereby be increased, these funds could be used to improve cost efficiency. To our knowledge, no prior research evidence has been reported in this respect. Accordingly, the following hypothesis is tested.

Hypothesis 4c: There is a positive relationship between cost efficiency and commercial debt.

In addition to the above types of borrowing, we examine indicators related to compliance with borrowing limits (PérezLópez et al., 2014). The indicator of the latter factor is taken as the ratio between outstanding debt and current municipal income; thus, the lower the ratio, the further the municipal finances will be from compliance with the $110 \%$ index, the legal limit for long-term investment ${ }^{4}$. In other words, the higher the value of this indicator, the fewer resources will be available to the municipality to devote to public services and, consequently, the less efficient it will be.

Although there is no empirical evidence of the relationship between this variable and cost efficiency, from its own definition, an increase in the value of the indicator for compliance with borrowing limits is expected to reduce cost efficiency, thus:

Hypothesis 5: There is an inverse relationship between compliance with borrowing limits and cost efficiency.

\section{Quality, political and socioeconomic factors explaining cost efficiency}

Other factors that may influence local government cost efficiency are those related to service quality, political aspects such as political orientation and type of municipal government, and socioeconomic factors such as absolute population, population density, size of population aged under 15 years and/or over 65 years, unemployment rate, economic activity and the local importance of tourism.

There is no concrete evidence of the relationship between the quality of municipal services and cost efficiency (Balaguer-Coll \& Prior, 2009). In principal, an increase in quality would imply higher spending and, therefore, that the municipality would be less efficient. On the other hand, according to the theory of Total Quality Management, investing in quality ultimately brings about increased cost efficiency (Prior, 2006).

The studies carried out to determine how the ideology of the governing party (i.e., the political condition) affects municipal cost efficiency have produced conflicting results (Vanden Eeckaut et al., 1993; Benito \& Bastida, 2004; Bastida et al., 2009; Kalb et al., 2012). In some cases, governments with a conservative majority have been found to achieve greater cost efficiency (Borge et al., 2008; Kalb et al., 2012; Da Cruz \& Marques, 2014), but in others government by progressive parties has been associated with higher levels of municipal cost efficiency (De Borger et al., 1994; Benito et al., 2010; Geys et al., 2010).

\footnotetext{
${ }^{4}$ Article 53 of Legislative Decree 2/2004, of 5 March, approving the Consolidated Text of the Local Government Finance Act, and Final Provision No. 31 of Act 17/2012, of 27 December, on the General Budget of the State for the year 2013 .
} 
In this context, it is also important to consider whether the party that governs the municipality does so with an absolute majority or in coalition. In the former case, the government should have less difficulty in achieving more efficient management than if a coalition with other parties has to be negotiated and maintained (Benito et al., 2018). Such a coalition government might incorporate different styles of management and even experience policy conflicts among the parties responsible for municipal government. Empirical evidence shows that strong political leadership (Borge et al., 2008) and a high number of votes for the strongest party (Bruns \& Himmler, 2011) both have a positive influence on municipal cost efficiency. In contrast, other studies have reported finding a relationship between political fragmentation and cost efficiency (Vanden Eeckaut et al., 1993; Balaguer-Coll et al., 2007; Borge et al., 2008). According to Kalb et al. (2012), this relationship would be explained by the political control exerted over government partners giving rise to more efficient management.

In relation to the local population, larger municipalities might achieve greater cost efficiency in services and facilities, thanks to economies of scale (De Borger et al., 1994; Giménez \& Prior, 2007; Benito et al., 2010; Bruns \& Himmler, 2011), but would also have to respond to greater numbers of users and provide more services. This obligation would be accentuated if, in addition, there were a high density of population, since the higher the population density, the larger the population served by the available infrastructure and services, and this could produce negative effects from diseconomies of agglomeration (Borowiecki, 2013). In fact, our review of previous empirical evidence shows that there is no generally accepted view on the relationship between population size and cost efficiency; some studies have reported a positive relationship in this respect (De Borger et al., 1994; De Borger \& Kerstens, 1996; Giménez \& Prior, 2007; Benito et al., 2010; Bruns \& Himmler, 2011) while others have observed the opposite (Dubin \& Navarro, 1988; Giménez \& Prior, 2007).

What is well established, though, is that the distribution and characteristics of the local population can affect municipal cost efficiency. When there is a large population of inhabitants aged over 65 years, this can have a positive effect on local government cost efficiency, as these residents are able to exercise greater control over local policies, due to their lower opportunity cost in obtaining information (Bosch et al., 2012). On the other hand, Da Cruz and Marques (2014) created an aging index, incorporating both older and younger population groups (those aged over 65 and under 15 years), and reported that both groups require greater spending on public services. They concluded that the higher this index, the lower the level of municipal cost efficiency.

With respect to local unemployment, contradictory evidence has been reported. According to Sung (2007) and PérezLópez et al. (2015), a higher rate of unemployment is associated with lower cost efficiency, since as the number of jobless persons increases, fewer resources will be available to maintain public services, and if the same quantity and level of services are to be provided, this could lead to cost inefficiency. On the other hand, Kalb et al. (2012) affirm that a higher unemployment rate will improve efficiency by reducing pressure on the quality of public services, thus resulting in lower costs for the municipality.

Regarding economic activity, Balaguer-Coll (2002) concluded that a higher level of economic activity improves cost efficiency; however, other studies, such as Giménez and Prior (2007) and Balaguer-Coll and Prior (2009), have analysed this question and concur that in municipalities with higher levels of economic or commercial activity, policymakers will be exposed to greater pressure to manage local services efficiently.

To conclude this review of socioeconomic factors, it is also important to consider the effect of tourism on the municipality. When this activity is significant, it requires a certain level of services, and increased demand in this respect may lead to greater cost efficiency in municipal government (Diez-Ticio \& Mancebón, 2002). In contrast, Giménez and Prior (2007), Bosch et al. (2012) and Da Cruz and Marques (2014) all argue that an increase in the local index of tourist activity is associated with higher costs in terms of congestion and the seasonality of services, and hence cost inefficiency.

\section{Methodology}

The research aims of this study are addressed by means of a two-stage analysis, following Simar and Wilson (2007), Balaguer-Coll et al. (2007, 2009), Balaguer-Coll and Prior (2009), Bosch et al. (2012), Cuadrado-Ballesteros et al. (2013) and Pérez-López et al. (2015), among others. In the first stage, the cost efficiency of various local public services is measured for each municipality in the sample, by the order$\mathrm{m}$ frontier method. In the second, a truncated regression of panel data with fixed effects is applied, following Prior et al. (2008), Pascual Arzoz et al. (2008), Bastida et al. (2013) and Pérez-López et al. (2015). This process reveals which variables exert most influence on municipal cost efficiency.

\subsection{Sample selection}

The study hypotheses were tested using a sample of municipalities in the Canary Isles (Spain). These islands are commonly excluded from efficiency studies due to their special, insular characteristics (Balaguer-Coll \& Prior, 2009; ZafraGómez et al., 2009a). Nevertheless, it is essential to analyse such a region in order to determine how dependence on tourism may affect the provision of local public services, a question that has received little previous research attention. The municipalities analysed are located within the autonomous community (region) of the Canary Isles, which is the second most important in Spain for domestic tourism (accounting for $17 \%$ of the national total). In turn, Spain was fourthranked in the world by number of foreign tourists in 2010 . The present research contributes new knowledge on the impact made by the 2008 Great Recession on cost efficiency, a consequence referred to in a previous study of transboundary crises (Ansell et al., 2010). The 77 municipalities in the study sample represent $87.5 \%$ of the total number of municipalities (88) in the islands. These 77 in particular were included because a more complete data set was available for them than for the others, with respect to the study period, thus enabling us to address one of the main study goals, that of breaking down municipal borrowing into commercial and financial debt.Specifically, the study sample contains data from municipalities with fewer than 50,000 inhabitants ${ }^{5}$. This characteristic arises from the fact that the data for the outputs of local public services were obtained from the Spanish Survey of Local Equipment and Infrastructure (EIEL), participation in which is not mandatory for municipalities with over

\footnotetext{
${ }^{5}$ Towns and cities with over 50,000 inhabitants were excluded because EIEL does not collect this information for large municipalities. This limitation is also found in studies by Balaguer-Coll et al. (2007); Zafra-Gómez and Muñiz (2010), Pérez-López et al. (2015), Pérez-López et al. (2016) and Pérez-López et al. (2018), among others.
} 
50,000 inhabitants (which in the Canary Isles is the case of eight municipalities). In addition, three municipalities that were required to provide this information (all in the island of El Hierro) did not in fact do so until 2013 and so these, too, were excluded from the sample.

\subsection{The order-m method of measuring cost efficiency (Stage 1).}

Various analyses based on frontier methods have been conducted to evaluate the efficiency of the local public sector. Most of these studies focus on inputs, in the assumption that outputs are determined by the institutional context that unifies the goods and public services to be provided, although measures of output quality are often included (Cabasés et al., 2007). Balaguer-Coll et al. (2007), among others, pointed out that since in most cases outputs are totally or partially determined by forces beyond the control of the local corporation, it seems more logical to evaluate efficiency in terms of minimising inputs.

Among the various types of frontier analysis that may be considered, many recent studies of local government efficiency have applied non-parametric models. However, these models can present estimation problems since the efficiency estimates obtained by data envelopment analysis (DEA) and Free Disposal Hull (FDH) methods are very directly correlated (Simar \& Wilson, 2007). Moreover, both methods are very sensitive to outliers and extreme values, since they incorporate all the data points (Daraio \& Simar, 2007; BalaguerColl et al., 2013); in addition, they are susceptible to measurement errors, because they assume the absence of statistical noise (De Witte \& Marques, 2010). Kneip et al. (1998) and Simar and Wilson (2007) were among the first studies that attempted to overcome the non-robustness of non-parametric methods (Cordero et al., 2013). In this respect, Cazals et al. (2002) and Simar (2003) introduced the concept of order-m frontiers, suggesting that efficiency should be evaluated with respect to a partial frontier rather than a complete one. By repeating the evaluation of the subsets of observations taken at random from the sample, a robust approach can be configured. Moreover, this approach makes it possible to perform the statistical inference of the efficiency indicators calculated, something which traditional non-parametric models do not allow. The order-m frontier method, accepting the non-convexity of the $\mathrm{FDH}$, resolves the presence of extreme values, allowing the location of observations beyond the estimated efficiency frontier, and therefore the borders do not include all the data (Simar \& Wilson, 2007).

The algorithm for calculating order-m efficiency coefficients considers a positive fixed integer " $m$ ", such that from a certain level of input $\left(x_{o}\right)$ and output $\left(y_{o}\right)$, the estimate defines the expected maximum value of $m$ random variables $\left(Y_{1}, \ldots, Y_{m}\right)$, extracted from the distribution of the output matrix $Y$, which satisfies the condition $Y_{m} \leq y_{o}$ (Balaguer-Coll et al., 2013). Therefore, the following steps should be taken to calculate the order-m estimator (Daraio \& Simar, 2007):

1. For a given level of $y_{0}$, extract a random sample of size $\mathrm{m}^{6}$ as a substitute for $\mathrm{y}_{\mathrm{sm}}$, such that $y_{s m} \leq y_{o}$.

2. Using the random sub-sample, estimate the efficiency coefficient $\tilde{a}_{\mathrm{s}}$.

${ }^{6}$ In the present case, by employing the order-m frontier approach, we work with a cluster value of 50 observations, that is, $m=50$, since the sensitivity analysis performed, with different values of $\mathrm{m}$, revealed a degree of convergence in the results for this value.
3. Repeat steps 1 and 2 , B times ${ }^{7}$. In each round, a coefficient of efficiency is estimated, such that by the end of the process we have B coefficients of efficiency $\tilde{a}_{S}^{b}(b=1 ; 2 ; \ldots ; B)$.

4. Finally, the arithmetic mean of the estimated efficiency coefficients is calculated as:

$$
\alpha_{S}^{m}=\frac{1}{B} \sum_{b=1}^{B} \tilde{a}_{S}^{b}
$$

In the present study, the selection of study variables is based on those used in previous empirical research (De Borger \& Kerstens 1996; Balaguer-Coll et al., 2007; Giménez \& Prior, 2007; Balaguer-Coll \& Prior, 2009; Benito et al., 2010; Geys et al., 2010; Da Cruz \& Marques, 2014; Ibarzola et al., 2017), taking into account the availability of information.

The inputs selected were the amounts of the respective chapters of the expenditure budget, following previous empirical studies of municipal cost efficiency such as those by Zafra-Gómez and Muñiz (2010), Cuadrado et al. (2013) and Pérez-López et al. (2015), considering current and capital expenses and excluding financial expenses (Chapters 1, 2, 4, 6 and 7). Budget settlement data were included in order to avoid the inclusion of provisional data, and consolidated data were used, in order to avoid the possible masking of data through the use of instrumental agencies (Fresneda \& Hernández, 2018). The information on inputs was obtained from the website of the Ministry of Finance and Public Administration, via the General Secretariat for Regional and Local Coordination ${ }^{8}$.

To define the outputs, we analysed the competences assigned to these municipalities under applicable legislation ${ }^{9}$, using proxies in order to avoid difficulties in directly evaluating the product or service provided. Most of these municipal services are described by the indicators included in the EIEL, as presented on the website of the Ministry of Finance and Public Administration (State Secretariat for Public Administration) and in the Unifica internet application made available by the Government of the Canary Isles. Therefore, the variables selected for each entity were the total budget in euros, as the input measure, and the number of inhabitants, the length of the road network (m), the volume of waste production (tons), the area of public facilities (sq. m.), the number of street lamps, the length of the water distribution network (m) and the surface area of cemeteries (sq. m.), as the output measures.

\subsection{Truncated bootstrap regression with panel data (Stage 2).}

The research hypotheses were tested by applying the proposal of Simar and Wilson (2007) to the results obtained in the first stage, using a truncated bootstrap regression with panel data, with fixed effects. This method was chosen because alternative procedures, such as OLS and Tobit models, have been criticised in the sense that correlation problems could arise between the first and second-stage variables, possibly invalidating the results of the statistical inference (Fernández-Santos et al., 2015). Furthermore, as observed

\footnotetext{
${ }^{7}$ Although in most applications it is reasonable to use $\mathrm{B}=200$ (BalaguerColl et al., 2013), in the present study $B=2,000$ is assumed, as suggested by De Witte and Geys (2013).

8 http://serviciosweb.meh.es/apps/EntidadesLocales/ consulted in June 2015. Except data from the municipality of Betancuria (Fuerteventura) for the year 2010, since this information was not on the Ministry's website. Instead, it was obtained directly from the municipality.

${ }^{9}$ Article 26 LRBRL specifies the powers of the municipalities.
} 
Table 1

Description of the variables included in Stage $2^{10}$

\section{VARIABLE}

\section{DEFINITION}

Municipal cost efficiency (dependent variable)

Index of budget sustainability

Level of government transfers received

Short-term borrowing

Long-term borrowing

Financial debt (short and long term)

Commercial debt

Compliance with borrowing limits

Net saving

Fiscal pressure per capita

Population density

Population tranche

Population aged under 15 years

Population aged over 65 years

Index of unemployment

Index of economic activity

Index of tourist activity

Index of average quality ${ }^{11}$

Political orientation of municipal government

Type of municipal government
Ratio of municipal spending to municipal services. Normally takes values between 0 and 1 , but as the order-m method allows superefficiency values, values greater than one may be obtained.

Ratio of expenditure (in chapters 1-7) and income (chapters 1-7).

Current and capital transfers from other public entities as a percentage of total income

Short-term consolidated municipal debt.

Long-term consolidated municipal debt.

Consolidated municipal debt owed to financial entities.

Consolidated municipal debt owed to budget and non-budget creditors and to other public entities.

Compliance with the borrowing limits imposed by national regulations, i.e. $<110 \%$ of outstanding debt, in relation to current income.

Current income less current expenses, less debt amortisation.

Tax revenue in relation to the number of inhabitants.

Surface area $\left(\mathrm{km}^{2}\right)$ of the municipality in relation to the number of inhabitants.

Categorical variable that classifies municipalities by population size: $0-5000$, ppn=0; 5001 20000, ppn=1; 20001-50000, ppn=2.

Number of inhabitants aged under 15 years in relation to the total number of inhabitants.

Number of inhabitants aged over 65 years in relation to the total number of inhabitants.

Number of persons unemployed in relation to the total number of inhabitants.

Tax income from total business activities (industrial, commercial and services) and professional activities in relation to the national total and in relation to the total number of inhabitants of the municipality.

Tax income from economic activities in the tourism sector in relation to the national total and in relation to the total number of inhabitants of the municipality.

Variable measuring the average quality of local public services, each of which is assigned the value 1, 2 or 3, corresponding to an evaluation of Poor, Fair or Good quality, respectively. For refuse collection, the quality values used are Sufficient $=2$ or Insufficient $=1$.

Variable assigned the following values, according to the orientation of the Mayor's political party: Progressive $=0$; Conservative $=1$

Variable assigned the following values, according to the type of governing majority of the Mayor's political party: Absolute=0; Coalition=1.

Source: The authors.

10 Our analysis of financial condition does not include liquidity because when the study was performed the data for this variable were not available in the Local Information System of the Canary Isles Autonomous Community (Unifica, the official website of the Canary Isles regional government) for the municipalities analysed in this period, and its inclusion would mean losing part of the sample.

11 The Quality Indicator is composed of the following quality indices obtained from the EIEL: condition of highway infrastructure, condition of the refuse collection network, condition of public equipment, condition of street lamps, condition of the water distribution network. In addition, equipment with the status "in the process of implementation" is excluded from the results since it is not currently being used and therefore is not providing any service to the local inhabitants. In the case of road infrastructure, in some cases the level of quality is stated as "unpaved" which we categorise as poor quality. 
by Balaguer-Coll et al. (2007), many two-stage studies are inconsistent because they assess efficiency (in the first stage) using non-parametric analysis, but consider the explanatory factors in the (second stage) by a parametric method.

The general specification of the truncated regression model used in our approach is described by the following equation:

$$
\alpha_{\mathrm{Si}}^{m}=a+\beta_{1} \mathrm{Z}_{1, i t}+\beta_{2} \mathrm{Z}_{2, i t}+\beta_{3} \mathrm{Z}_{3, i t}+\beta_{4} \mathrm{Z}_{4, i t}+\varepsilon_{i}
$$

where:

$$
i=1,2, \ldots, 77 \text { (municipalities) }
$$$$
t=2008, \ldots, 2012 \text { (years) }
$$

$\alpha_{\mathrm{Si}}^{m}$ is the dependent variable represented by the efficiency obtained for each municipality (obtained in the first stage).

$a$ is a constant term.

$\mathrm{Z}_{1, \text { it }}$ is the vector of the financial explanatory variables.

$\mathrm{Z}_{2, \text { it }}$ is the vector of the political explanatory variables.

$Z_{3, \text { it }}$ is the explanatory variable of service quality.

$\mathrm{Z}_{4, \text { it }}$ is the vector of the socioeconomic explanatory variables.

$\beta_{1, \ldots, 4}$ are the vectors of the parameters to be estimated in the second stage, which determine the relationship between the independent variables and the dependent variable.

$\varepsilon \mathrm{i}$ is the independent error term (or statistical noise), normally-distributed $\mathrm{N}\left(0, \delta_{\varepsilon}^{2}\right.$, and left truncated at $(1-\widehat{\beta} \mathrm{Zi})$.

Table 1 details the second stage variables used in the study. These were chosen taking into account the methods adopted in previous empirical studies in this field, such as De Borger et al. (1994), Balaguer-Coll et al. (2007), Balaguer-Coll and Prior (2009), Benito et al. (2010), Bosch et al. (2012) and Pérez-López et al. (2015), and according to the availability of information and the legal framework applicable to these local entities. The information related to these variables was obtained from the following sources: the Ministry of Finance and Public Administrations (Secretariat for Regional and Local Administration and the Virtual Office for the Financial Coordination of Local Entities); the National Institute of Statistics (INE); the Survey of Local Equipment and Infrastructure (EIEL); the Unifica website of the Autonomous Government of the Canary Isles; the Economic Yearbook published by La Caixa; the website of the Ministry of the Interior; and the websites of relevant political parties.

\section{Analysis of results: relationship between cost efficiency, financial condition and debt}

This section presents the results obtained in the first and second stages, which are used to test the research hypotheses.

Table 2 shows the descriptive statistics of the variables included in the first stage of the analysis.

The descriptive statistics for each year of the first-stage variables are shown in Annex 1. Notably, the average total
Table 2

\begin{tabular}{|c|c|c|c|c|c|}
\hline Variable & Mean & Median & $\begin{array}{l}\text { Standard } \\
\text { deviation }\end{array}$ & Maximum & Minimum \\
\hline Total cost (euros) & $3,388,847$ & $8,643,118$ & $12,451,851$ & $77,448,391$ & $1,279,124$ \\
\hline No. of inhabitants (n) & 12,865 & 8,605 & 11,085 & 44,007 & 772 \\
\hline Length of street network (m) & 113,097 & 92,895 & 73,042 & 309,058 & 11,390 \\
\hline Waste production (Tn) & 18,178 & 5,105 & 60,627 & 465,361 & 141 \\
\hline Public equipment $\left(\mathrm{m}^{2}\right)$ & 212,355 & 139,881 & 229,194 & $1,362,507$ & 13,715 \\
\hline Street lamps (n) & 2,323 & 1,821 & 1,850 & 8,166 & 249 \\
\hline $\begin{array}{l}\text { Length of the water distribution } \\
\text { network }(m)\end{array}$ & 81,747 & 58,740 & 65,679 & 286,530 & 9,227 \\
\hline Surface area of cemeteries $\left(\mathrm{m}^{2}\right)$ & 6,293 & 4,105 & 7,770 & 57,012 & 760 \\
\hline
\end{tabular}

Descriptive statistics: input and output variables (2008-2012)

Source: The authors, from data published by the Ministry of Finance and Public Administration.

Municipal cost efficiency by population tranche (2008-2012)

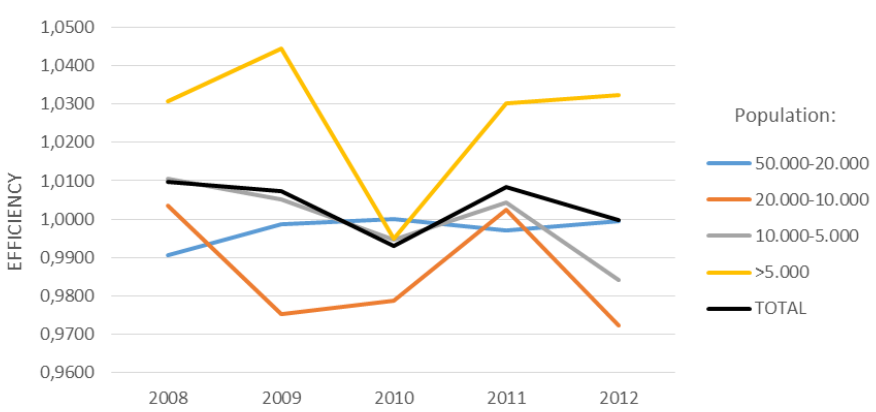

budget costs fell during the study period, as did the standard deviation, i.e. the data had a lower level of dispersion. The total volume of waste decreased, but all other output variables increased during the same period. In general, the standard deviation of the data increased, except that for the total area of cemeteries.

The results for municipal efficiency are shown in Table 3.

The above values show that, on average, these municipalities achieve a very high level of cost efficiency. Those with fewer than 5,000 inhabitants obtain the highest values in this respect during most of the period, while those with 10-20,000 inhabitants usually obtain the worst results. Overall, average cost efficiency decreased during the study period, from 1.0097 to 0.9997 . The pattern of cost efficiency varies according to the size of the population (see Fig. 1). Thus, in the larger municipalities, the cost efficiency increased slightly during the study period, whilst it decreased in the others, with the exception of municipalities with fewer than 5,000 inhabitants, where the level of cost efficiency remained unchanged overall, although with marked variations in the intermediate periods. In general, a worsening of the average cost efficiency was perceived for all population tranches between 2008 and 2012.

The descriptive statistics for the second-stage variables and the matrix of correlations are presented in Annexes 2 and 3, respectively. There is no collinearity, and so the variance inflation factor (VIF) was determined. According to the empirical rule proposed by Kutner et al. (2004), problems of collinearity arise when VIF $>10$. In the present case, the average value obtained was 3.24. None of the dependent variables obtained high values (the highest was 6.98), from which it can be concluded that there is no correlation between the explanatory variables of the model. In addition, the standard deviations obtained show that, in general, the data do not present a large degree of dispersion, except for per capita fiscal pressure and for population density.

Table 4 shows the results of the truncated regression with panel data, performed to test the study hypotheses, obtained using each of the above individual estimates as an independent variable. 
Table 3

Cost efficiency of Canary Isles municipalities by population tranche 2008-2012

\begin{tabular}{cllllllllll}
\hline & \multicolumn{2}{c}{$\mathbf{2 0 0 8}$} & \multicolumn{2}{c}{$\mathbf{2 0 0 9}$} & \multicolumn{2}{c}{$\mathbf{2 0 1 0}$} & \multicolumn{2}{c}{$\mathbf{2 0 1 1}$} \\
\cline { 2 - 10 } Population (thousands) & Mean & S.D. & Mean & S.D. & Mean & S.D. & Mean & S.D. & Mean & S.D. \\
\hline $50-20$ & 0.9905 & 0.0403 & 0.9988 & 0.0050 & 1.0000 & 0.0000 & 0.9970 & 0.0136 & 0.9994 & 0.0270 \\
$20-10$ & 1.0035 & 0.0068 & 0.9753 & 0.0779 & 0.9788 & 0.0732 & 1.0025 & 0.0150 & 0.9724 & 0.0658 \\
$10-5$ & 1.0105 & 0.0663 & 1.0052 & 0.0495 & 0.9947 & 0.0695 & 1.0043 & 0.0438 & 0.9842 & 0.0702 \\
$<5$ & 1.0306 & 0.1834 & 1.0445 & 0.0883 & 0.9948 & 0.0779 & 1.0302 & 0.0994 & 1.0322 & 0.0759 \\
TOTAL & 1.0097 & 0.1016 & 1.0072 & 0.0661 & 0.9930 & 0.0628 & 1.0084 & 0.0563 & 0.9997 & 0.0644 \\
\hline
\end{tabular}

Table 4

Empirical results of the estimation of the determinants of municipal cost efficiency

\begin{tabular}{|c|c|c|}
\hline Variable & Expected sign & Value \\
\hline Index of budget sustainability & - & $-0.1135 * * *$ \\
\hline $\begin{array}{l}\text { Level of government transfers } \\
\text { received }\end{array}$ & $+/-$ & -0.0842 \\
\hline Net savings & + & 0.0007 \\
\hline Fiscal pressure per capita & - & $-0.0001^{*}$ \\
\hline Short-term borrowing & - & $-0.0232 * *$ \\
\hline Long-term borrowing & + & -0.0013 \\
\hline $\begin{array}{l}\text { Financial debt (short and long } \\
\text { term) }\end{array}$ & - & -0.0013 \\
\hline Commercial debt & + & $0.0076^{*}$ \\
\hline $\begin{array}{l}\text { Compliance with borrowing } \\
\text { limits }\end{array}$ & - & $-0.0718^{* *}$ \\
\hline Index of average quality & $+/-$ & $0.0906^{*}$ \\
\hline $\begin{array}{l}\text { Political orientation of municipal } \\
\text { government }\end{array}$ & + & $-0.0450 * * *$ \\
\hline Type of municipal government & $+/-$ & 0.0162 \\
\hline Population tranche & $+/-$ & -0.0039 \\
\hline Population density & $+/-$ & $0.0008^{*}$ \\
\hline Population aged under 15 years & $+/-$ & -0.8607 \\
\hline Population aged over 65 years & $+/-$ & $2.0917 * * *$ \\
\hline Index of unemployment & $+/-$ & 0.5207 \\
\hline Index of economic activity & $+/-$ & $-0.0515^{*}$ \\
\hline Index of tourist activity & - & 0.0015 \\
\hline Dummy: 2009 & & $-0.0331 * *$ \\
\hline Dummy: 2010 & & $-0.0474 * * *$ \\
\hline Dummy: 2011 & & $-0.0511 * *$ \\
\hline Dummy: 2012 & & $-0.0930 * * *$ \\
\hline Constant & & $1.2797 * * *$ \\
\hline \multicolumn{3}{|l|}{$* \mathrm{p}<0.05 ; * * \mathrm{p}<0.01 ; * * * \mathrm{p}<0.001$} \\
\hline Index of robustness: $73.05 \%$ & & \\
\hline
\end{tabular}

The first analysis performed of these results concerned the influence of the financial variables on cost efficiency. The index of budget sustainability presents a negative sign and is statistically significant $(\mathrm{p}<0.001)$. Consequently, Hypothesis 1 is verified, corroborating the results obtained by BalaguerColl (2007), meaning that the higher the municipality's costs in relation to its income, the lower the cost efficiency. On the other hand, no significant evidence was obtained for a relation between the variable reflecting vulnerability - the level of transfers - and cost efficiency, unlike Geys (2006), De Borger and Kerstens (1996), Balaguer-Coll (2002), BalaguerColl et al. (2007), Giménez and Prior (2007), Balaguer-Coll and Prior (2009) and Bosch et al. (2012), who reported finding a significant relation between this variable and cost efficiency. Accordingly, Hypothesis 2 cannot be accepted.
Of the variables measuring flexibility, those analysed were related to net savings, per capita fiscal pressure, debt and compliance with the credit limit. In contrast to the findings of Geys (2006) and Pérez-López et al. (2014), net savings did not present a significant relationship with cost efficiency, and so Hypothesis 3 a cannot be accepted. On the other hand, fiscal pressure per capita presented a significant negative relationship $(\mathrm{p}<0.05)$ with cost efficiency, which supports Hypothesis $3 \mathrm{~b}$, and therefore we conclude that if the municipal government lost the power to generate current income it would be less motivated to manage its resources efficiently. These results coincide with those obtained by De Borger et al. (1994), Balaguer-Coll (2002), Giménez and Prior (2007), Balaguer-Coll et al. (2007), Balaguer-Coll and Prior (2009), Bosch et al. (2012) and Cuadrado-Ballesteros et al. (2013).

In relation to debt, in its various forms, which is the main object of this study, the variable short-term debt presents a significant negative relationship with cost efficiency $(\mathrm{p}<0.01)$, meaning that higher financial costs, due to higher levels of short-term debt, would reduce cost efficiency (Hypothesis 4a). These results coincide with those reported by Worthington (2000) and Geys (2006). In contrast, long-term debt does not present any significant relationship with cost efficiency (Hypothesis 4b), which suggests that long-term debt does not affect short-term management activities, since most of the budget values used to calculate cost efficiency correspond to current expenditure (Mugera \& Nyambane, 2015). This finding contrasts with Benito et al. (2010), who observed a significant positive relationship between long-term debt and cost efficiency. The results for commercial debt reveal a significant positive relationship with cost efficiency $(\mathrm{p}<0.05)$. Thus, for the first time there is shown to be a clear difference between commercial and financial debt in relation to municipal cost efficiency (and therefore Hypothesis $4 \mathrm{c}$ is accepted). This outcome could be interpreted as meaning that financial debt affects cost efficiency due to the impact produced on the municipal budget, unlike commercial debt, which does not impose greater costs on the municipality.

The indicator of compliance with the credit limit presents a significant negative relationship with cost efficiency $(p<0.01)$. Thus, the higher the credit limit, the fewer resources will be available to the municipality for public services and so the less cost efficient it will be (therefore, Hypothesis 5 is accepted).

In the second block of variables, we first considered the average quality of public services and facilities, obtaining evidence of a significant positive relationship with municipal cost efficiency $(\mathrm{p}<0.05)$, thus corroborating Zafra-Gómez and Muñiz (2010). In a previous study, Prior (2006) explained this relationship as the outcome of Total Quality Management, i.e. that investment in quality produces a corresponding increase in cost efficiency.

In line with De Borge et al. (1994), Benito et al. (2010), Geys et al. (2010) and Borge et al. (2008), we find that polit- 
ical orientation is inversely associated with cost efficiency, and that the relation is statistically significant $(p<0.001)$. However, no evidence was obtained that the type of municipal government affects municipal cost efficiency. These findings coincide with Benito et al. (2010) and Pérez-López et al. (2015), according to whom municipalities that are governed by progressive political parties obtain higher levels of cost efficiency.

In relation to the socioeconomic variables, our results confirm, with different levels of significance, that greater population density is associated with higher levels of local government cost efficiency. There is also significant evidence that when the municipal population contains a higher proportion of older inhabitants, government cost efficiency is greater, which corroborates the results obtained by Bosch et al. (2012).

Finally, the index of economic activity has a significant inverse relationship with cost efficiency. However, no significant relationships were found with respect to unemployment, the index of activity in the tourism sector, the size of the local population aged under 15 years or the total population of the municipality.

\section{Conclusions and discussion}

The recent economic crisis has heightened the need to improve the allocation of resources and to limit public sector borrowing (in accordance with new regulations in this respect). This situation has spurred research interest in evaluating how well municipalities manage their affairs and in determining which factors have most influence on cost efficiency in this sector, especially those related to sources of finance and types of municipal debt.

The theoretical arguments considered in previous research indicate that, in general, public sector borrowing is inversely associated with cost efficiency, due (at least in part) to the higher spending and lower cost efficiency resulting from increased financial costs (Worthington, 2000; Geys, 2006; Benito el al., 2010; Da Cruz \& Marques, 2014; Cordero et al., 2017). In this context, we apply an order-m methodology (thus overcoming the limitations of DEA), followed by bootstrap truncated regression with panel data (as proposed by Simar and Wilson, 2007). The novel aspect of the present study is its emphasis on the need to distinguish between commercial and financial borrowing, having detected that the relationship between municipal debt and cost efficiency varies according to the type of debt incurred. We find that an increase in commercial debt is associated with greater cost efficiency, possibly derived from the absence of financial costs in this type of borrowing. Financial debt, on the other hand, impairs municipal cost efficiency. These results highlight the need for further study of the relationship between commercial debt and cost efficiency, taking into account that this relationship has been detected in municipalities of the Canary Isles (Spain) during the period of financial crisis, and should be corroborated by reference to other socioeconomic contexts.

Confirming previous research, we also detected a relationship between cost efficiency and other components of financial condition, namely budget sustainability, fiscal pressure and borrowing limits. But, in addition, we show that this relationship exists in periods of transboundary crisis.

The results obtained show that, in times of crisis, progressive governments obtain better levels of cost efficiency than conservative ones, that greater service quality improves cost efficiency and that certain socioeconomic variables impact on the cost efficiency achieved.

The implications drawn from the present study are clear and important from the standpoint of local government management and financing. In a context of reduced spending, characterised by the presence of a transboundary crisis, an increase in commercial debt can bring about efficiency improvements in municipalities where the tourism industry plays an important role, while resorting to short-term financial debt worsens cost efficiency. Municipal managers in such areas should take these circumstances into account when considering their financing options during periods of financial recession.

A limitation of the present study, but also an indication of an area of interest for future research, is the need to expand the study to address other regions, in order to examine our hypotheses of cost efficiency vs. commercial and financial debt in other municipal contexts. Furthermore, other methods of analysis should be considered, such as the DEA-data panel approach used by Surroca et al. (2016), which takes into account the unobservable heterogeneity in the units evaluated, or the DEA-data panel models developed by PérezLópez et al. (2018) for determining scale efficiency.

\section{Acknowledgements}

We are grateful for the financial support received from Ministerio de Educación y Ciencia (Spain; ECO2013-48413-R, ECO2016-76578-R and ECO2017-88241-R).

\section{Conflict of interests}

The authors declare no conflict of interests.

\section{References}

Ansell, C., Boin, A., \& Keller, A. (2010). Managing transboundary crises: identifying the building blocks of an effective response system. Journal of Contingencies and Crisis Management, 18(4), 195-207.

Andrews, R., \& Entwistle, T. (2013). Four faces of public service efficiency: What, how, when and for whom to produce. Public Management Review, 15(2), 246-264.

Atan, R., Raman, S. A., Sawiran, M. S., Mohamed, N., \& Mail, R. (2010). Financial Performance of Malaysian Local Authorities: A Trend Analysis. In International Conference on Science and Social Research, 271-276. Kuala Lumpur, December 5-8. CSSR.

Balaguer-Coll, M. T. (2002). Análisis de la situación financiera y la eficiencia en las administraciones locales. Instituto de Contabilidad y de Auditoría de Cuentas.

Balaguer-Coll, M. T. (2004). La eficiencia en las administraciones locales ante diferentes especificaciones del output. Hacienda Pública Española, 170, 37-58.

Balaguer-Coll, M. T., \& Prior, D. (2009). Short-and longterm evaluation of efficiency and quality. An application to Spanish municipalities. Applied Economics, 41(23), 29913002.

Balaguer-Coll, M. T., Prior, D., \& Tortosa-Ausina, E. (2007). On the determinants of local government performance: A two-stage nonparametric approach. European Economic Review, 51(2), 425-451.

Balaguer-Coll, M. T., Prior, D., \& Tortosa-Ausina, E. (2013). Output complexity, environmental conditions, and the effi- 
ciency of municipalities. Journal of Productivity Analysis, 39(3), 303-324.

Bastida, F. J., Benito, B., \& Guillamón, M. D. (2009). An empirical assessment of the municipal financial situation in Spain. International Public Management Journal, 12(4), 484-499.

Bastida, F., Beyaert, A., \& Benito, B. (2013). Electoral cycles and local government debt management. Local Government Studies, 39(1), 107-132.

Benito, B., \& Bastida, F. J. (2004). The determinants of the municipal debt policy in Spain. Journal of Public Budgeting, Accounting and Financial Management, 16(4), 525-558.

Benito, B., Guillamón, M.D., Ríos, A.M., \& Bastida, F. (2018). Can salaries and re-election prevent political corruption? An empirical evidence, Revista de ContabilidadSpanish Accounting Review, 21 (1), 19-27.

Benito, B., Bastida, F. J., \& García, J. A. (2010). Explaining differences in efficiency: An application to Spanish municipalities. Applied Economics, 42(4), 515-528.

Bisogno, M., \& Cuadrado-Ballesteros, B. (2018). Explaining the relation between efficiency and financial condition: empirical analysis on local governments. In Financial Sustainability and Intergenerational Equity in Local Governments (pp. 149-178). IGI Global.

Borge, L., Falch, T., \& Tovmo, P. (2008). Public sector efficiency: The roles of political and budgetary institutions, fiscal capacity, and democratic participation. Public Choice, 136(34), 475-495.

Borowiecki, K. J. (2013). Agglomeration economies in classical music. Papers in Regional Science, in press. https: //doi.org/10.1111/pirs.12078.

Bosch, N., Espasa, M., \& Mora, T. (2012). Citizen control and the efficiency of local public services. Environment and Planning-Part C, 30(2), 248.

Bruns, C., \& Himmler, O. (2011). Newspaper circulation and local government efficiency. The Scandinavian Journal of Economics, 113(2), 470-492.

Cabaleiro, R., Buch, E., \& Vaamonde, A. (2013). Developing a method to assessing the municipal financial health. The American Review of Public Administration, 43(6), 729-751.

Carmeli, A. (2002). A conceptual and practical framework of measuring performance of local authorities in financial terms: analysing the case of Israel. Local Government Studies 28 (1): 21-36.

Cazals, C., Florens, J., \& Simar, L. (2002). Nonparametric frontier estimation: A robust approach. Journal of Econometrics, 106(1), 1-25.

Canadian Institute of Chartered Accountants. (1997). Indicators of government financial condition. Toronto, Ontario, Canada: CICA.

Canadian Institute of Chartered Accountants. (2009). Public sector statements of recommended practice (SORP) 4. Indicators of financial condition. Toronto, Ontario, Canada: CICA.

Cabasés, F., P. Pascual y J. Valles (2007), The Effectiveness of Institutional Borrowing Restrictions: Empirical Evidence from Spanish Municipalities, Public Choice, 131 (3), pp. 293313.

Congleton, R. (2002). The Median Voter Model. In CK Rowley (Ed.); F. Schneider (Ed.) (2003). The Encyclopedia of Public Choice.

Cordero, J.M., Pedraja-Chaparro, F., Pisaflores, E. C., \& Polo, C. (2017). Efficiency assessment of Portuguese municipalities using a conditional nonparametric approach. Journal of Productivity Analysis, 48(1), 1-24.

Cordero, J. M., Prior, D., \& Simancas, R. (2013). A com- parison of public and private schools in Spain using robust nonparametric frontier methods. Central European Journal of Operations Research, 1-22.

Cuadrado-Ballesteros, B., \& Bisogno, M. (2018). Efficiency as a determinant of financial condition: an assessment of Italian and Spanish local governments. International Public Management Journal, (just-accepted), 1-58.

Cuadrado-Ballesteros, B., García-Sánchez, I. M., \& PradoLorenzo, J. M. 1. (2013). Effect of modes of public services delivery on the efficiency of local governments: A two-stage approach. Utilities Policy, 26, 23-35.

Da Cruz, N. F., \& Marques, R. C. (2014). Revisiting the determinants of local government performance. Omega, 44, 91-103.

Daraio, C., \& Simar, L. (2007). Advanced robust and nonparametric methods in efficiency analysis: Methodology and applications. Springer Science \& Business Media.

De Borger, B., \& Kerstens, K. (1996). Cost efficiency of Belgian local governments: A comparative analysis of FDH, DEA, and econometric approaches. Regional Science and Urban Economics, 26(2), 145-170.

De Borger, B., Kerstens, K., Moesen, W., \& Vanneste, J. (1994). Explaining differences in productive efficiency: An application to Belgian municipalities. Public Choice, 80(3-4), 339-358.

De Sousa, Maria Da Conceição Sampaio, \& Stoi, B. (2005). Technical efficiency of the brazilian municipalities: Correcting nonparametric frontier measurements for outliers. Journal of Productivity Analysis, 24(2), 157-181.

De Witte, K., \& Geys, B. (2013). Citizen coproduction and efficient public good provision: Theory and evidence from local public libraries. European Journal of Operational Research, 224, 592-602.

De Witte, K., \& Marques, R. C. (2010). Influential observations in frontier models, a robust non-oriented approach to the water sector. Annals of Operations Research, 181(1), 377-392.

Diez-Ticio, A., \& Mancebón, M. (2002). The efficiency of the Spanish police service: An application of the multiactivity DEA model. Applied Economics, 34(3), 351-362.

Dijkgraaf, E., Gradus, R.H.J.M., \& Melenberg, B. (2003). Contracting out refuse collection. Empirical Economics, 28 (3), 553-570.

Dubin, J. A., \& Navarro, P. (1988). How markets for impure public goods organize: The case of household refuse collection. Journal of Law, Economics, \& Organization, , $217-$ 241.

Fernández Santos, Y., Martínez Campillo, A., \& Fernández Fernández, J. M. (2015). Determinantes de la eficiencia en las universidades públicas españolas: Un análisis DEA en dos etapas. XIV Jornadas De Economía De La Educación. Madrid. Asociación De Economía De La Educación,

Fresneda, S., \& Hernández, J. (2018). Institutional capacity in the accounting reform process in Spanish local governments. Revista de Contabilidad - Spanish Accounting Review, 21 (2), 188-195, https://doi.org/10.1016/j.rcsar.2018.05. 002

Geys, B. (2006). Looking across borders: A test of spatial policy interdependence using local government efficiency ratings. Journal of Urban Economics, 60(3), 443-462.

Geys, B., Heinemann, F., \& Kalb, A. (2010). Voter involvement, fiscal autonomy and public sector efficiency: Evidence from German municipalities. European Journal of Political Economy, 26(2), 265-278.

Giménez, V. M., \& Prior J., D. (2007). Longand shortterm cost efficiency frontier evaluation: Evidence from Spanish 
local governments. Fiscal Studies, 28(1), 121-139.

Government of Western Australia: Department of Local Government. 2013. Local Government Operational Guidelines: Financial Ratios, 18. Perth: Department of Local Government.

Greenberg, J., \& Hillier, D. (1995). Indicators of financial condition for governments. 5th Conference of Comparative International Governmental Accounting Research. ParisAmy.

Groves, M., Godsey, W., \& Shulman, M. (2003). Evaluating Financial Condition: A Handbook of Local Government (3rd ed.). Washington, DC: International City Management Association.

Hammer, R. B., \& Green, G. P. (1996). Local growth promotion: Policy adoption versus effort. Economic Development Quarterly, 10(4), 331-341.

Hendrick, R. M. (2011). Managing the fiscal metropolis: The financial policies, practices, and health of suburban municipalities Georgetown University Press.

Ibarloza Arrizabalaga, A., Erkizia Olaizola, A., Malles Fernández, E. (2017). Implantación de una metodología cooperativa de cálculo de costes de los servicios públicos locales. Revista de Contabilidad-Spanish Accounting Review, 20 (2), 210-224.

Kalb, A., Geys, B., \& Heinemann, F. (2012). Value for money? German local government efficiency in a comparative perspective. Applied Economics, 44(2), 201-218.

Kneip, A., Park, B. U., \& Simar, L. (1998). A note on the convergence of nonparametric DEA estimators for production efficiency scores. Econometric Theory, 14(06), 783-793.

Kutner, M. H., Nachtsheim, C., \& Neter, J. (2004). Applied linear regression models. McGraw-Hill/Irwin.

López-Hernández, A., Prior J., D., Zafra-Gómez, J. L., \&Plata Díaz, A. M. (2012). Determinando el impacto del entorno socioeconómico y de las formas de gestión sobre la eficiencia en la prestación de servicios públicos locales de Andalucía. Fundación Pública Andaluza Centro de Estudios Andaluces. Junta de Andalucía.

López-Hernández, A.M., Zafra-Gómez, J. L., Plata Díaz, A. M., \& de la Higuera-Molina, E. J. (2017). Modeling fiscal stress and contracting out in local government: The influence of time, financial condition, and the great recession. The American Review of Public Administration, 48 (6), 565-583. https://doi.org/10.1177/0275074017699276.

Mugera, A. W., \& Nyambane, G. G. (2015). Impact of debt structure on production efficiency and financial performance of broadacre farms in Western Australia. Australian Journal of Agricultural and Resource Economics, 59(2), 208-224.

NarbónPerpiñá, I., \& De Witte, K. (2018a). Local governments' efficiency: a systematic literature review-part I. International Transactions in Operational Research, 25(2), 431468.

NarbónPerpiñá, I., \& De Witte, K. (2018b). Local governments' efficiency: a systematic literature review-part II. International Transactions in Operational Research, 25(2), 1107-1136.

Pascual Arzoz, P., Cabasés Hita, F., \& Ezcurra, R. (2008). Financiación, restricciones institucionales y endeudamiento: Un análisis con microdatos de los municipios de Navarra. XV Encuentro de Economía Pública.

Pérez-López, G., Plata-Díaz, A. M., Zafra-Gómez, J. L., \& López-Hernández, A. M. (2014). Operaciones fuera de presupuesto (off budget), factores políticos y deuda municipal: Un estudio empírico aplicando una metodología de datos de panel. Gestión y Política Pública, 23(1), 185-218.

Pérez-López, G., Prior, D., \& Zafra-Gómez, J. L. (2015).
Rethinking new public management delivery forms and efficiency: long-term effects in Spanish local government. Journal of Public Administration Research and Theory, 25(4), 1157-1183.

Pérez-López, G., Prior, D., Zafra-Gómez, J.L., \& Plata-Díaz, A.M. (2016). Cost efficiency in municipal solid waste service delivery. Alternative management forms in relation to local population size. European Journal of Operational Research, 255, 583-592. doi:10.1016/j.ejor.2016.05.034.

Pérez-López, G., Prior, D., \& Zafra-Gómez, J. L. (2018). Temporal scale efficiency in DEA panel data estimations. An application to the solid waste disposal service in Spain. Omega,76, 18-27.

Plata-Díaz, A. M., de la Higuera-Molina, E. J., GarridoRodríguez, J. C., \& Zafra-Gómez, J. L. (2017). Contracting out and social services: responses to the austerity machine, financial condition and political parties. Administration \& Society, in press, https://doi.org/10.1177/ 0095399717713797.

PricewaterhouseCoopers. 2006. National Financial Sustainability Study of Local Government: Commissioned by the Australian Local Government Association. Sydney, NSW: LGA.

Prieto, A. M., \& Zofio, J. L. (2001). Evaluating effectiveness in public provision of infrastructure and equipment: the case of Spanish municipalities. Journal of productivity Analysis, 15(1), 41-58.

Prior, D. (2006). Efficiency and total quality management in health care organizations: A dynamic frontier approach. Annals of Operations Research, 145(1), 281-299.

Prior, D., Surroca, J., \& Tribó, J. A. (2008). Are socially responsible managers really ethical? Exploring the relationship between earnings management and corporate social responsibility. Corporate Governance: An International Review, 16(3), 160-177.

Simar, L. (2003). Detecting outliers in frontier models: A simple approach. Journal of Productivity Analysis, 20(3), 391-424.

Simar, L., \& Wilson, P. W. (2007). Estimation and inference in two-stage, semi-parametric models of production processes. Journal of Econometrics, 136(1), 31-64.

Sung, N. (2007). Information technology, efficiency and productivity: Evidence from korean local governments. Applied Economics, 39(13), 1691-1703.

Tiebout, C. M. (1956). A pure theory of local expenditures. Journal of Political Economy, 64(5), 416-424.

Turley, G., Robbins, G., \& McNena, S. (2015). A framework to measure the financial performance of local governments. Local Government Studies, 41(3), 401-420.

Vanden Eeckaut, P., Tulkens, H., \& Jamar, M. (1993). Cost efficiency in Belgian municipalities. The Measurement of Productive Efficiency-Techniques and Applications, 300-334.

Wang, X., Dennis, L., \& Sen,Y. (2007). Measuring financial condition: A study of U.S. states. Public Budgeting and Finance, 27(2), 1-21.

Worthington, A. C. (2000). Cost efficiency in Australian local government: A comparative analysis of mathematical programming and econometrical approaches. Financial Accountability \& Management, 16(3), 201-223.

Zafra-Gómez, J. L., Hernández Bastida, A., \& LópezHernández, A. (2006). Evaluación de la condición financiera en las administraciones locales a través del análisis de componentes principales. Presupuesto y Gasto Público, 43, 113-126.

Zafra-Gómez, J. L., \& López-Hernández, A. (2006). La valoración de la condición financiera en los ayuntamien- 
tos andaluces. Auditoría Pública: Revista de los Órganos Autónomos de Control Externo, (39), 41-52.

Zafra-Gómez, J. L., López-Hernández, A., \& HernándezBastida, A. (2009a). Developing a model to measure financial condition in local government evaluating service quality and minimizing the effects of the socioeconomic environment: An application to Spanish municipalities. The American Review of Public Administration, 39(4), 425-449.

Zafra-Gómez, J. L., López-Hernández, A. M., \& HernándezBastida, A. (2009b). Evaluating financial performance in local government: maximizing the benchmarking value. International Review of Administrative Sciences, 75(1), 151167.

Zafra-Gómez, J. L., \& Muñiz Pérez, A. (2010). Overcoming cost-inefficiencies within small municipalities: Improve financial condition or reduce the quality of public services? Environment and Planning.C, Government \& Policy, 28(4), 609-629. 
Table Annex 1

Descriptive statistics of input and output variables, by year

\begin{tabular}{|c|c|c|c|c|c|c|c|c|c|c|}
\hline & \multicolumn{2}{|c|}{2008} & \multicolumn{2}{|c|}{2009} & \multicolumn{2}{|c|}{2010} & \multicolumn{2}{|c|}{2011} & \multicolumn{2}{|c|}{2012} \\
\hline & Mean & S.D. & Mean & S.D. & Mean & S.D. & Mean & S.D. & Mean & S.D. \\
\hline Total cost (thousands of euros) & 13,730 & 11,762 & 14,640 & 12,970 & 13,569 & 12,710 & 13,558 & 13,191 & 11,448 & 11,626 \\
\hline No. of inhabitants (n) & 12,559 & 10,704 & 12,787 & 10,959 & 12,894 & 11,100 & 13,015 & 11,245 & 13,069 & 11,416 \\
\hline Length of street network (m) & 99,367 & 62,930 & 115,435 & 75,246 & 118,288 & 76,857 & 115,935 & 75,020 & 116,459 & 75,160 \\
\hline Waste production (Tn) & 12,032 & 15,099 & 8,948 & 10,922 & 8,884 & 10,647 & 10,486 & 18,161 & 10,541 & 18,305 \\
\hline Public equipment $\left(\mathrm{m}^{2}\right)$ & 201,642 & 207,599 & 211,201 & 241,476 & 215,825 & 233,415 & 213,476 & 230,256 & 219,632 & 233,222 \\
\hline Street lamps (n) & 2,209 & 1,730 & 2,329 & 1,907 & 2,356 & 1,867 & 2,401 & 1,902 & 2,318 & 1,843 \\
\hline $\begin{array}{l}\text { Length of the water distribution } \\
\text { network (m) }\end{array}$ & 77,732 & 60,586 & 78,497 & 61,278 & 84,947 & 69,281 & 84,164 & 68,013 & 83,396 & 69,234 \\
\hline Surface area of cemeteries $\left(\mathrm{m}^{2}\right)$ & 6,191 & 7,887 & 6,244 & 7,857 & 6,313 & 7,702 & 6,316 & 7,702 & 6,399 & 7,702 \\
\hline
\end{tabular}

Table Annex 2

Descriptive statistics of the second-stage variables and variance inflation factor (VIF)

\begin{tabular}{|c|c|c|c|c|c|c|}
\hline VARIABLE & MEAN & MEDIAN & $\begin{array}{l}\text { STANDARD } \\
\text { DEVIATION }\end{array}$ & MINIMUM & MAXIMUM & VIF \\
\hline MUNICIPAL EFFICIENCY & 1.003599 & 1 & 0.071952 & 0.537322 & 1.557485 & \\
\hline INDEX OF BUDGET SUSTAINABILITY & 0.969930 & 0.958446 & 0.139215 & 0.523109 & 1.619950 & 1.4 \\
\hline $\begin{array}{l}\text { LEVEL OF GOVERNMENT TRANSFERS } \\
\text { RECEIVED }\end{array}$ & 0.588158 & 0.600236 & 0.174148 & 0.160724 & 0.959501 & 5.35 \\
\hline SHORT-TERM BORROWING & 14.880690 & 14.908130 & 1.186554 & 11.479450 & 17.366010 & 3.72 \\
\hline LONG-TERM BORROWING & 14.563010 & 14.717250 & 1.653298 & 7.453046 & 17.515700 & 3.16 \\
\hline FINANCIAL DEBT & 14.745870 & 15.004000 & 1.692731 & 7.071955 & 17.639760 & 2.24 \\
\hline COMMERCIAL DEBT & 14.630770 & 14.656460 & 1.226376 & 6.057557 & 17.060300 & 2.36 \\
\hline COMPLIANCE WITH BORROWING LIMITS & 0.385593 & 0.336378 & 0.304140 & 0 & 1.798995 & 1.89 \\
\hline NET SAVINGS & 13.699520 & 13.696310 & 1.388470 & 5.895036 & 16.641880 & 2.45 \\
\hline FISCAL PRESSURE PER CAPITA & 431.932200 & 346.530000 & 246.656500 & 102.07000 & 1491.210000 & 6.98 \\
\hline INDEX OF SERVICE QUALITY & 2.435642 & 2.448859 & 0.160990 & 1.781336 & 2.759871 & 1.27 \\
\hline POITICAL ORIENTATION & 0.163636 & 0 & 0.370427 & 0 & 1 & 1.22 \\
\hline TYPE OF MUNICIPAL GOVERNMENT & 0.420779 & 0 & 0.494327 & 0 & 1 & 1.36 \\
\hline POPULATION TRANCHE & 0.989610 & 1 & 0.710704 & 0 & 2 & 4.56 \\
\hline INDEX OF UNEMPLOYMENT & 0.107202 & 0.107918 & 0.026992 & 0.043742 & 0.174494 & 1.84 \\
\hline INDEX OF ECONOMIC ACTIVITY & 0.983667 & 0.671893 & 1.101559 & 0 & 10.057220 & 1.47 \\
\hline INDEX OF TOURISM ACTIVITY & 7.175759 & 0.785855 & 14.375890 & 0 & 66.829270 & 4.39 \\
\hline POPULATION AGED UNDER 15 YEARS & 0.135765 & 0.139684 & 0.026380 & 0.060270 & 0.188756 & 7.02 \\
\hline POPULATION AGED OVER 65 YEARS & 0.165357 & 0.161954 & 0.058262 & 0.056045 & 0.315292 & 7.3 \\
\hline POPULATION DENSITY & 291.988100 & 179.199500 & 454.809300 & 6.561173 & 3759.106000 & 1.49 \\
\hline MEAN VIF & & & & & & 3.24 \\
\hline
\end{tabular}


Table Annex 3

Correlation matrix of study variables

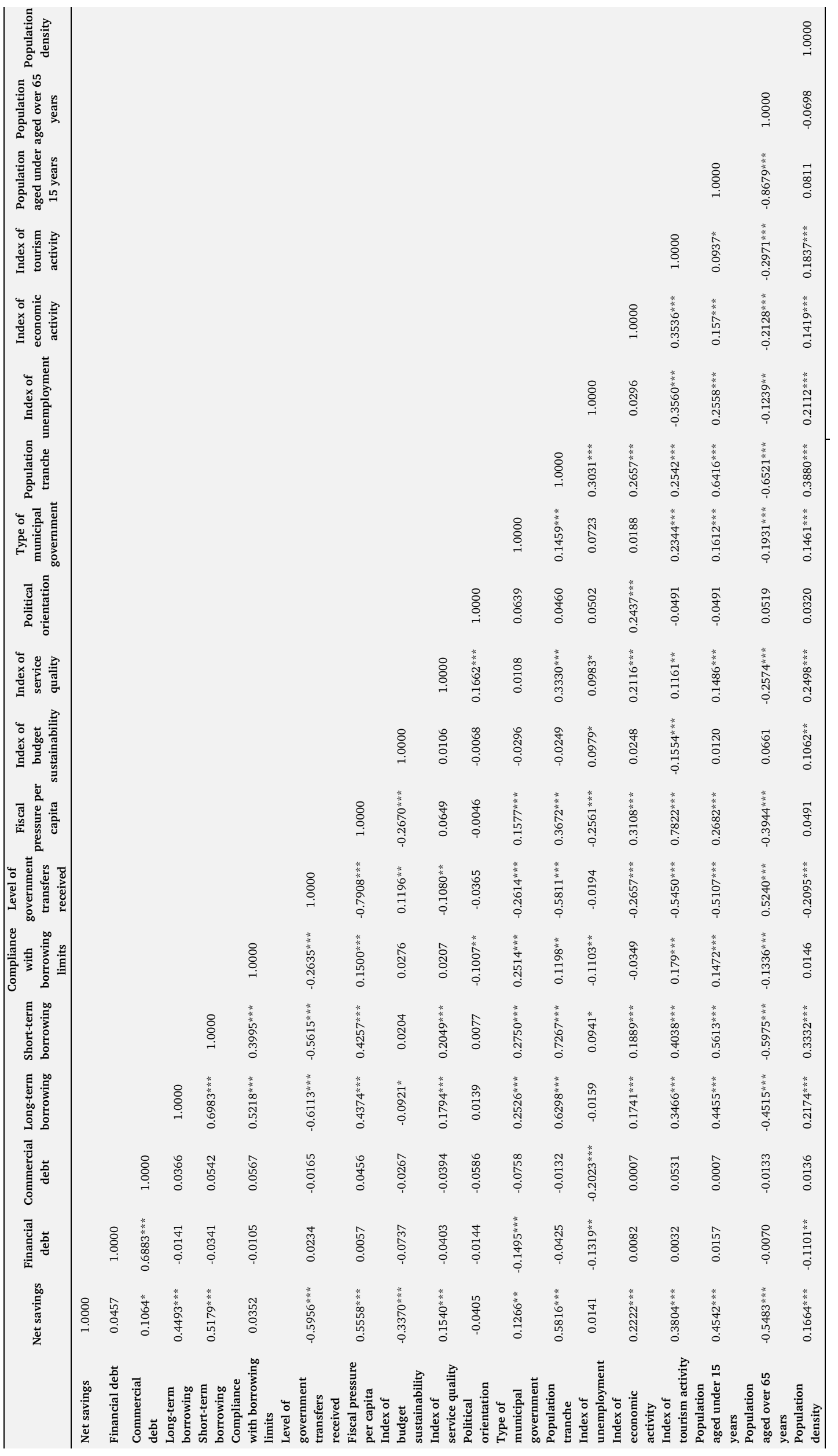

